\title{
S100 Calcium-Binding Protein B Measurement
}

National Cancer Institute

\section{Source}

National Cancer Institute. S100 Calcium-Binding Protein B Measurement. NCI Thesaurus. Code C127635.

The determination of the amount of S100 calcium-binding protein B present in a sample. 